\title{
Modified Technique of Porcelain Laminate Veneer in Premolars with Abfraction Lesions: Three-Dimensional Finite Element Analysis (FEA)
}

\section{Técnica Modificada de Laminado Cerâmico em Pré-Molar com Lesão de Abfração: Análise Tridimensional Por Elementos Finitos (FEA)}

\author{
Larissa Marcia Martins Alves*a; Lisseth Patricia Claudio Contreras ${ }^{\mathrm{b}}$; João Paulo Mendes Tribst ${ }^{\mathrm{b}}$; \\ Renata Marques de Meloc; Alexandre Luiz Souto Borges ${ }^{\mathrm{c}}$
}

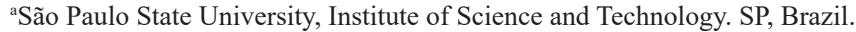
'bão Paulo State University, Institute of Science and Technology at São José dos Campos. SP, Brazil. 'São Paulo State University, Institute of Science and Technology at São José dos Campos, Department of Dental Materials and Prosthodontics. SP, Brazil. *Email: larissammalves@gmail.com

Recebido em: 26/02/2020

Aprovado em: 29/05/2020
\end{abstract}

\begin{abstract}
The incidence of non-carious cervical lesions (NCCLs) has increased as populations are aging, and teeth are increasingly retained for life. Several materials are available to treat these lesions. This study aimed to evaluate the stress distribution of maxillary premolars with NCCLs using three-dimensional (3D) finite element analysis (FEA) according to different restorative techniques. A 3D FEA mathematical model simulating a sound premolar was initially modeled and replicated in 6 more models simulating a tooth with abfraction: G.1 tooth with abfraction; G.2 tooth with abfraction + composite resin restoration; G.3 tooth with abfraction + glass-ionomer cement restoration; G. 4 tooth with abfraction + resin composite restoration + porcelain laminate veneers; G.5 tooth with abfraction + glass-ionomer cement + porcelain laminate veneers; and G.6 modified porcelain laminate veneers filling the lesion. All materials and structures were considered linear, elastic, homogeneous and isotropic and the results were expressed as maximum principal stress. Lower stress concentration in dentin was calculated when the tooth was restored with composite resin and glass-ionomer cement. Regarding the veneer techniques, no difference was found to dentin stress among the groups, but the modified veneer concentrated less stress in the restoration than other the techniques. The control group had the highest concentration of stress in the lesion. All techniques decreased the stress concentration inside the NCCLs and the indirect veneer filling the lesion presented better biomechanical behavior than the veneer cemented above direct restorations.
\end{abstract}

Keywords: Finite Element Analysis. Dental Veneers. Ceramics. Bicuspid.

\section{Resumo}

A incidência de lesões cervicais não-cariosas (LCNC) tem aumentado, uma vez que a população tem envelhecido com uma menor perda de elementos dentários. Diferentes materiais estão disponiveis para tratar dessas lesões. Este estudo objetivou avaliar a distribuição de tensão de pré-molares superiores com LCNC por meio da análise tridimensional (3D) de elementos finitos (FEA) de acordo com diferentes técnicas restauradoras. Um modelo matemático $3 \mathrm{D}$ FEA simulando um pré-molar íntegro foi modelado e replicado em mais 6 modelos simulando um dente com abfração: G.1 dente com abfração; G.2 dente com abfração + resina composta; G.3 dente com abfração + cimento de ionômero de vidro; G.4 dente com abfração + resina composta + faceta; G.5 dente com abfração + cimento de ionômero de vidro + faceta cerâmica e G. 6 com faceta cerâmica modificada, preenchendo a lesão. Todos os materiais e estruturas foram considerados lineares, elásticos, homogêneos e isotrópicos e os resultados foram expressos como máxima tensão principal. Menor concentração de tensão na dentina foi calculada quando o dente foi restaurado com resina composta ou cimento de ionômero de vidro. Dentre os grupos com laminados, não houve diferença para a dentina, entretanto a faceta modificada apresentou menor concentração de tensão na restauração. O grupo controle apresentou a maior concentração de tensão na lesão. Todas as técnicas restauradoras diminuíram a concentração de tensão no interior das LCNCs e dentre as técnicas com laminados a faceta modificada apresentou o melhor comportamento biomecânico.

Palavras-chave: Análise de Elementos Finitos. Facetas Dentárias. Cerâmica. Dente Pré-Molar.

\section{Introduction}

The incidence of non-carious cervical lesions (NCCLs) has increased as populations are aging and teeth are increasingly retained for life, but the etiology of these lesions is still a source of controversy. ${ }^{1,2}$ These lesions are multifactorial in nature and are characterized by the loss of hard dental tissue in the area near the cementum-enamel junction. Some factors may be associated with NCCLs such as, stress, friction (abrasion) and biocorrosion (erosion). ${ }^{3,4}$ The abfraction may occur due to occlusal loads during parafunction, occlusion and swallowing, causing tooth flexion, resulting in microfractures and structural loss of dental tissue in the cervical region. ${ }^{5}$

The higher prevalence of non-carious cervical lesions in premolars is justified in the concepts of biomechanics, since the cervical constriction that these teeth present generates greater stress concentration in this region $^{6}$, and also the smaller area of the periodontal ligament results in a smaller capacity to absorb occlusal loads. ${ }^{7}$

The main indications to treat these lesions are sensitivity and aesthetic deficiency ${ }^{8}$ and for that, several materials are available on dentistry, each with their advantages and 
disadvantages. Glass ionomer, composite resin and ionomermodified resin are the most common materials used to rehabilitate cervical lesions..${ }^{910}$ However, composites provide an immense challenge to the restoration marginal integrity, because undergo polymerization contraction and are materials harder to achieve an ideal surface polished..$^{11,12}$

Dental ceramics, such as feldspathic and lithium disilicate, could offer advantages for this restoration due to their ability to reproduce and maintain long-term surface color and texture, as well as wear resistance; however, the material compliance should be considered. ${ }^{8}$ The best advantage of this technique, when it is correctly executed, is the possibility of obtaining good aesthetics in restorations and obtaining satisfactory biocompatibility, and enabling performance of gingival repositioning surgeries. ${ }^{13}$

Planning is of great importance in successful rehabilitation and some studies evaluated different materials and techniques in order to achieve better clinical outcomes in cases of noncarious cervical lesions. ${ }^{14-16}$ Thus, this study aimed to evaluate the stress distribution of maxillary premolars with NCCLs using three-dimensional (3D) finite element analysis (FEA) according to different restorative techniques. The tested null hypothesis was that the biomechanical behavior of premolars with NCCLs is not affected by the restorative technique.

\section{Material and Methods}

\subsection{FEA}

This study was conducted using a 3-dimensional (3D) FEA method and specific software (ANSYS 17.0; ANSYS Inc, Houston, TX) to perform a structural mechanical analysis. Schematic illustrations of the geometries are shown in Figure 1.

Figure 1 - (a-n) A schematic illustration of the sequentially performed procedures

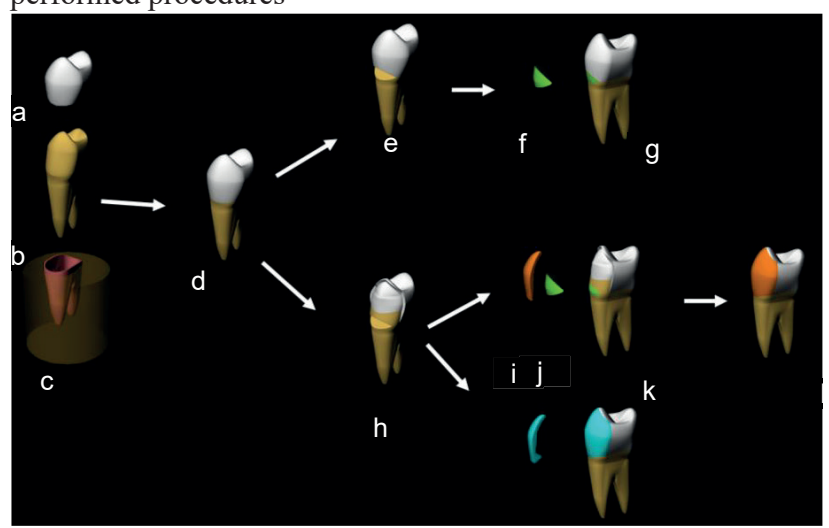

(a-d) A schematic illustration of a salutary pre-molar. (a) enamel, (b) dentin, (c) periodontal ligament and (d) tooth. (e-g) A schematic illustration of a premolar with a surface lesion and restored. (e) premolar with surface lesions, (f) restoration, (g) restored tooth. (h-m) A schematic illustration of a premolar with a surface lesion and laminate veneers preparation with two restorative techniques. (h) premolar with a surface lesion and laminate veneers preparation, (i) laminate veneers, $(j)$ restoration, $(\mathrm{k})$ tooth with a surface lesion restored in dentin, (1) tooth restored with laminate veneer, (m) modified laminate veneer, $(\mathrm{n})$ tooth restored with modified laminate veneer. Source: Authors.

\subsection{Preprocessing}

A 3D FEA mathematical model simulating a maxillary premolar tooth ${ }^{17}$ was created using CAD (Rhinoceros version 5.0SR8; McNeel North America, Seattle, WA) (Figurew 1a-c). Two more models (NCCL, and NCCL + veneer preparation) were then created from this model (sound tooth). The 2 experimental groups were subdivided according to restorative material, resulting in 6 models: G. 1 control group (tooth with lesion); G.2 tooth with abfraction lesion + resin composite restoration; G.3 tooth with abfraction lesion + glass-ionomer cement restoration; G.4 tooth with abfraction lesion + resin composite restoration + porcelain laminate veneers; G.5 tooth with abfraction lesion + glass-ionomer cement + porcelain laminate veneers; G.6 modified porcelain laminate veneers.

The abfraction lesion present in groups 1 to 6 were made wedge-shaped and an enamel bevel were created. Composite resin restoration and glass-ionomer cement restoration were made in groups 2 and 3, respectively. In group 4, a resin composite restoration filling the lesion was created associated with ceramic laminate veneers with $0.5 \mathrm{~mm}$ thickness. In group 5, a glass-ionomer cement restoration filling the lesion associated with porcelain laminate veneers with $0.5 \mathrm{~mm}$ thickness were performed; and in group 6, modified ceramic laminate veneers filling the lesion with ceramic material $(0.5$ $\mathrm{mm}$ thickness at the buccal surface and $0.8 \mathrm{~mm}$ thickness at the lesion area) were performed (Figure 1). All ceramic veneer preparations were simulated only exposing enamel without cusp reduction. The simulated resin composite was from Clearfil APX (Kuraray Noritake, Japan) and the glass ionomer cement was from Photac ${ }^{\mathrm{TM}}$ Fil Quick Aplicap ${ }^{\mathrm{TM}}$ (3M ESPE, Saint Paul, MN, USA). The ceramic veneers were produced from a feldspathic ceramic (Vita PM9, Vita Zahnfabrik, Germany).

All materials were considered homogenous, linearly elastic and isotropic. Corresponding elastic properties such as the Young modulus (E) and Poisson ratio were determined from the literature (Table 1). All geometries were exported in STEP format to the computer aided engineering software (ANSYS 17.0; ANSYS Inc, Houston, TX) for mechanical static structural analysis. All contacts between surfaces were considered perfectly bonded. The mesh was created with tetrahedral quadratic elements. Each mathematical model included a different number of nodes and tetrahedral solid elements (Table 2). The exterior surface of the root was fixed ensuring only the movement constraint on the $\mathrm{Z}$ axis so that the stress generated in all directions was computed. 
Table 1 - Distribution of the Mechanical Properties of the Materials

\begin{tabular}{|c|c|c|c|}
\hline $\begin{array}{c}\text { Structure/ } \\
\text { Material }\end{array}$ & $\begin{array}{c}\text { Elastic } \\
\text { Modulus (GPa) }\end{array}$ & $\begin{array}{c}\text { Poisson } \\
\text { Ratio }\end{array}$ & Reference \\
\hline Enamel & 84.1 & 0.33 & Roscoe et al. $^{18}$ \\
\hline Dentin & 18.6 & 0.32 & Soares et al. $^{19}$ \\
\hline Pulp & 2 & 0.45 & Farah et al. $^{20}$ \\
\hline Ligament & 0.069 & 0.45 & $\begin{array}{c}\text { Joshi et al. }{ }^{21} \text { and } \\
\text { Singh et al. }\end{array}$ \\
\hline Vita PM9 & 44.4 & 0.26 & Trindade et al. $^{23}$ \\
\hline $\begin{array}{c}\text { Resin } \\
\text { composite }\end{array}$ & 15.3 & 0.3 & Kok et al..$^{24}$ \\
\hline $\begin{array}{c}\text { Glass-ionomer } \\
\text { cement }\end{array}$ & 10.6 & 0.30 & Magni et al..$^{25}$ \\
\hline
\end{tabular}

Source: Research data.

Table 2 - Groups names, numbers of nodes and tetrahedral elements, stress peaks and Tukey test

\begin{tabular}{|c|c|c|c|c|}
\hline Groups & Nodes & $\begin{array}{c}\text { Tetrahedral } \\
\text { Elements }\end{array}$ & $\begin{array}{c}\text { Maximum } \\
\text { Principal } \\
\text { Stress (MPa })\end{array}$ & $\begin{array}{c}\text { Tukey test } \\
(\alpha=5 \%)\end{array}$ \\
\hline G1 & 115.396 & 65.314 & $43.99 \pm 6.0$ & A \\
\hline G2 & 116.775 & 65.898 & $30.87 \pm 7.1$ & B \\
\hline G3 & 116.775 & 65.898 & $26.60 \pm 6.2$ & C \\
\hline G4 & 120.074 & 67.473 & $27.18 \pm 4.3$ & BC \\
\hline G5 & 120.074 & 67.473 & $26.78 \pm 4.1$ & C \\
\hline G6 & 121.961 & 68.573 & $22.22 \pm 2.1$ & D \\
\hline
\end{tabular}

Source: Research data.

The load of $150 \mathrm{~N}$ was applied on the top of the buccal cusp at an inclination of $45^{\circ}$ with the tooth long axis ${ }^{26}$ for calculating the maximum principal stress. The results of the stress distributions are presented in graphics with a color scale in $\mathrm{MPa}$ (Figures 2 e 3), taking into account the failure criteria (tensile stress). The higher stress peaks were exported from analysis software $(\mathrm{n}=32)$ and analyzed by One-way ANOVA and Tukey's test (5\%), and these data were subsequently plotted in a distribution plot according to frequency and magnitude.

Figure 2 - Stress distribution in the restorative material according to the implemented techniques
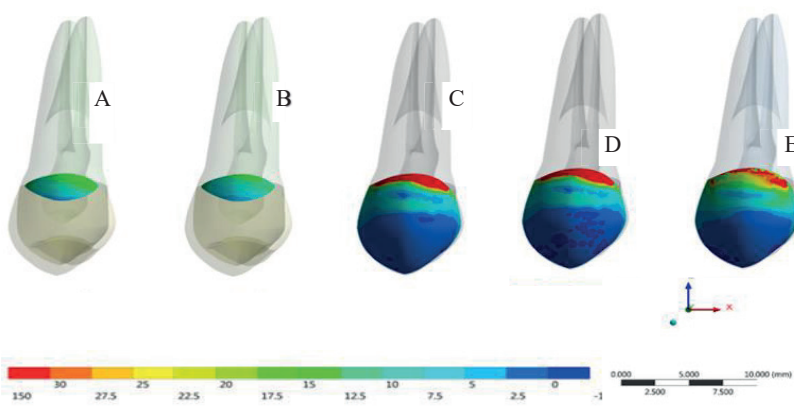

(A) resin composite restoration; (B) glass-ionomer cement restoration; (C) resin composite restoration + porcelain laminate veneer; (D) glassionomer restoration + porcelain laminate veneer; (E) modified porcelain laminate veneer. The red color corresponds to tensile stress, whereas blue corresponds to compression.

Source: Research data.
Figure 3 - Stress distribution in dentin according to the implemented techniques

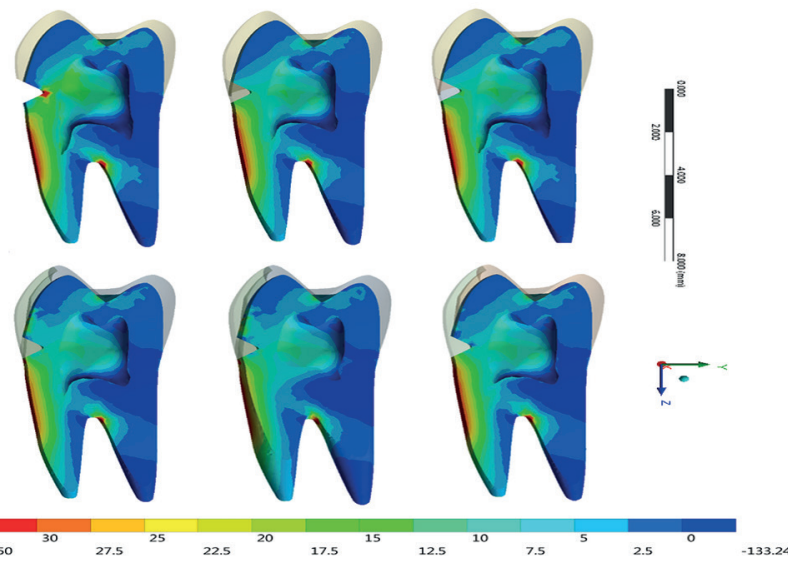

(A) tooth with lesion; (B) tooth with abfraction lesion + resin composite restoration; (C) tooth with abfraction lesion + glass-ionomer cement restoration; D) tooth with abfraction lesion + resin composite restoration + porcelain laminate veneer; (E) tooth with abfraction lesion + glassionomer restoration + porcelain laminate veneer; (F) modified porcelain laminate veneer. The red color corresponds to tensile stress, whereas blue corresponds to compression.

Source: Research data.

\section{Results and Discussion}

After obtaining the maximum principal stress for the restorations it was possible to perform a comparative analysis among the groups. Stress distribution in restorative techniques is shown in Figure 2. It is possible to observe (through the red color) the high tensile stress concentration areas. It is also possible to notice lower stress concentration in dentin when the tooth was restored with composite resin or glass-ionomer cement (Figure 3). In addition, there was no difference for stress concentration in the root dentin among the veneer restorative techniques, but the modified veneer concentrated less stress in the material than the other groups (Figure 2). The control group presented the highest stress inside the lesion cavity (Figure 3A).

One-way ANOVA (Table 3) showed a statistically significant difference for the stress concentration on teeth according to the restorative technique $(\mathrm{p}=0.001)$.

Table 3 - Analysis of variance (One-way) of the maximum stress data generated in the teeth $(\mathrm{MPa})$

\begin{tabular}{|c|c|c|c|c|c|}
\hline $\begin{array}{c}\text { Source of } \\
\text { Variation }\end{array}$ & $\begin{array}{c}\text { Degrees of } \\
\text { Freedom }\end{array}$ & $\begin{array}{c}\text { Sum of } \\
\text { squares }\end{array}$ & $\begin{array}{c}\text { Mean } \\
\text { Square }\end{array}$ & F & -value \\
\hline Stress & 5 & 9148 & 1829.61 & 61.16 & $0.001^{*}$ \\
\hline Residual & 186 & 5565 & 29.92 & & \\
\hline Total & 191 & 14713 & & & \\
\hline
\end{tabular}

* Statistical significance $(\mathrm{p}<0.05) ; \mathrm{F}=\mathrm{F}$-Test statistic.

Source: Research data.

The abfraction lesion without restoration showed higher stress concentration than the other groups $(43 \mathrm{MPa})^{\mathrm{A}}$. No difference was found among the teeth restored with composite resin $(30 \mathrm{MPa})^{\mathrm{B}}$ and this material associated with an indirect veneer $(26 \mathrm{MPa})^{\mathrm{BC}}$ as well as when the teeth was restored with 
glass ionomer cement $(26 \mathrm{MPa})^{\mathrm{C}}$ and received an indirect veneer $(26 \mathrm{MPa})^{\mathrm{C}}$, but the modified indirect veneer reduced the stress concentration in the cavity surface $(22 \mathrm{MPa})^{\mathrm{D}}$. The distribution plot shows increased frequency of reduced stress peaks for G6 in comparison with other treatments (Figure 4).

Figure 4 - Distribution plot of stress peak frequency for all restored groups. The more the curve is shifted to the left, the lower the stress concentration. The higher the curve, the more homogenous the stress distribution

Histogram of Stress

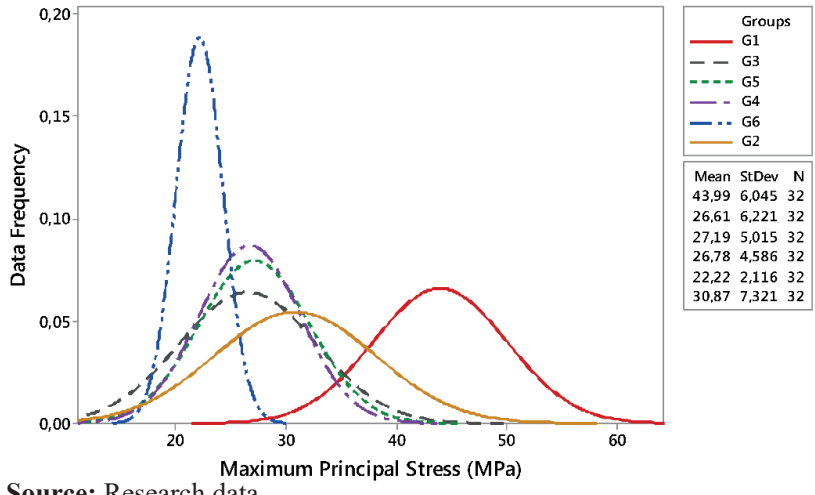

Source: Research data.

The null hypothesis that there would be no difference in the biomechanical behavior of premolars restored with several techniques was rejected. The abfraction lesions may be influenced by occlusal loads, which weaken the dental structure with fatigue and stress concentration, ${ }^{27}$ generating micro-cracks and resulting in the loss of enamel and dentin structures. ${ }^{28,29}$ The abfraction lesion can affect the biomechanical behavior of the tooth, ${ }^{30,31}$ thus is important replace the lost structures with restorative materials.

In addition, some studies showed the higher prevalence of this kind of injury in premolar, probably due the lower capacity this tooth support oblique forces during chewing and lateral movement guided by group function. ${ }^{7,14,32}$ Besides that, its anatomy diminish the capacity of support loads, since premolar has less structure than molars and cervical constriction. ${ }^{17}$ Besides that, studies reported the higher incidence of NCCL in maxillary teeth, ${ }^{17,32,33}$ whereas others noticed this in mandibular. ${ }^{34,35}$ We chose a maxillary premolar due its higher lesion incidence and also because maxillary are teeth with greater aesthetic demand, since it is more visible than mandibular, ${ }^{36}$ and it will be discussed later.

Figure $3 \mathrm{~A}$ shows the stress concentration in dentin (lesion apex, red area) due to the loss of dental structure and the absence of a restorative material (G1); this increased stress could be harmful to the tooth, generating a lesion progression. These results are in agreement with studies which analyzed premolars with Class V lesion and found higher stress values in the teeth without restoration. ${ }^{37,38}$

However, there are several material options and restorative techniques to treat NCCL, including composite resins and glass ionomer cements, but there is no clinical consensus about the ideal material. Two composites were simulated
(G2 = composite resin and G3 = glass-ionomer cement) and showed similar behavior regarding the stress distribution in dentin (Figure 3B and 3C). However, the longevity of this restorations can be compromised by some factors such as polymerization shrinkage, fatigue resistance, secondary caries, marginal misfit, color change, or postoperative sensitivity ${ }^{39-42}$, being indicated replace them.

In addition to functional factors which justify the exchange of a restoration, a desire to improve smile aesthetics can also be understood as a reason to perform a restorative procedure, using an indirect material. Since, laminate veneers in ceramic presents higher survival rate and quality than in composite resin. ${ }^{43}$ In these cases, indirect ceramic veneers are widely used in esthetics rehabilitation and can be executed with conservative and minimally invasive preparations. ${ }^{44}$

Despite this, there is no restorative protocol to be followed in a clinical situation when the tooth has an abfraction lesion and an indirect veneer was selected as a restorative treatment. Herein a simulated veneer was performed above the direct restorative materials and a modified veneer was extended from the buccal face to the cervical lesion, reducing the number of clinical steps and interfaces.

Besides overcoming the limitations of direct materials, the tooth can be restored using materials with properties similar to a sound tooth, which means replace the dentin with composite resin or glass-ionomer and the enamel with ceramics (G4 and G5, respectively). ${ }^{27}$ A lower stress concentration in the dentin for the G4 and G5 groups can be observed in Figure 3D and 3E compared to the groups which received direct restorations and without restoration, probably because the ceramics present greater rigidity which generates greater stress accumulation in the restoration and lower in the tooth; our results corroborates with Dejak and Mlotkowski findings. ${ }^{45}$

This result was also observed in G6, where a restorative technique with a modified veneer was proposed, restoring both dentin and enamel with a feldspathic ceramic (G6). This model presented closer stress distribution to the G4 and G5 groups in the sagittal section (Figure 3F), but with a slightly lower stress concentration area. The difference is better observed after the statistical analysis (Table 3), in which the G6 stress peaks were significantly lower than the other groups.

This result may be associated with the fact that, ceramic has higher elastic modulus than composite resin and glassionomer cement (Table 1), thereby a ceramic rehabilitation that filled the lesion generates less stress concentration in the dental remnant. Since higher elastic modulus of the restorative material less deformation and stress concentration at dental structures under the same stress. ${ }^{46}$ With this, it can be said that this method provides a restoration less susceptible to infiltrations, fractures and failures by providing less stress in the tooth.

Although the G6 group has a higher stress concentration in the restoration, the applied force $(150 \mathrm{~N})$ does not reach the load for the ceramic fracture, which is $89 \mathrm{MPa}$ according 
to Choi et al. ${ }^{47}$, probably because it is a rigid material which contains more ceramic volume, therefore requiring more energy to reach its fracture. Given this, we can consider that the G6 presented the best stress distribution for this simulation.

It is important point out that the results depend on the position of load application ${ }^{48}$ and the literature reported that occlusal loads applied outside the long axis of the tooth produce more cervical stress than axially applied loads. ${ }^{49,50}$ In agreement of that, a higher incidence of NCCL can be found in patients that apply large eccentric occlusal loads. ${ }^{50}$ Because that, in the present study was tested the worst scenario using a $45^{\circ}$ of inclination to simulate a lateral movement, but distinct occlusal loads condition, e.g. load applied at the functional cusp, can result in different stress distribution at the demand structure and restorative material. ${ }^{27,51}$

From these results, it is possible noticed a better biomechanical behavior of modified ceramic veneer to treat class $\mathrm{V}$ lesion, because this technique generates less stress at the interface with dentin. With this we can expected less susceptibility to adhesive failures, lower probability of marginal misfit and percolation when compared to ceramic veneers cemented above direct restorations. Among the direct techniques, the materials presented a similar behavior, but the composite resin concentrated more stress in the restoration than the glass-ionomer cement (Figure 2A and 2B), and more stress in the tooth (Table 3 ). This difference can be explained by the different elastic modulus of the materials, since a material with greater modulus concentrates more stress in its structure. This result corroborates the findings of Machado et al. ${ }^{27}$

Thereby, based on the data from this study it is suggested to restore abfraction lesions in order to reduce the stress concentration on the tooth and possible injuries. The modified veneer showed the best biomechanical behavior to perform that but, is important consider that this is a silico study and in vitro and in vivo investigations are necessary to validate our results.

\section{Conclusion}

Within the limitations of this study, we can conclude that: All restorative techniques decreased the stress concentration in the non-carious lesion, therefore can be indicated as a treatment option;

Direct restorations are less susceptible to catastrophic failure, but induce greater stress in the dental tissue compared to indirect restorations;

The modified ceramic veneer filling the area of the noncarious lesion was the indirect treatment that presented the best biomechanical behavior.

\section{References}

1. NascimentoMM,DilboneDA,PereiraPN,DuarteWR, Geraldeli S, Delgado AJ. Abfraction lesions: etiology, diagnosis, and treatment options. Clin Cosmet Investig Dent 2016;8:79-

\section{7. doi: 10.2147/CCIDE.S63465.}

2. Haralur SB, Alqahtani AS, AlMazni MS, Alqahtani MK. Association of non-carious cervical lesions with oral hygiene habits and dynamic occlusal parameters. Diagnostics (Basel) 2019;12;9(2):43. doi: 10.3390/diagnostics9020043.

3. Grippo JO, Simring M, Coleman TA. Abfraction, abrasion, biocorrosion, and the enigma of noncarious cervical lesions: a 20-year perspective. J Esthet Restor Dent 2012;24(1):10-23. doi: 10.1111/j.17088240.2011.00487.x.

4. Nascimento MM, Dilbone DA, Pereira PN, Duarte WR, Geraldeli S, Delgado AJ. Abfraction lesions: etiology, diagnosis, and treatment options. Clin Cosmet Investig Dent 2016;8:79-87. doi: 10.2147/ CCIDE.S63465

5. Grippo JO, Simring M, Schreiner S. Attrition, abrasion, corrosion and abfraction revisited: new perspective on tooth surface e lesions. J Am Dent Assoc 2004;135(8):1109-18. doi: 10.14219/jada.archive.2004.0369

6. Pereira FA, Zeola LF, Almeida Milito G, Reis BR, Pereira $\mathrm{RD}$, Soares PV, Restorative material anda loading type infleunece on the biomechanical behavior of wedge shaped cervical lesions. Clin Orla Investig 2016;20(3):433-41. doi: 10.1007/s00784-015-1523-3.

7. Rees JS, Hammadeh M, Jagger DC. Abfraction lesion formation in maxillary incisors, canines and premolars: a finite elemente study. Euro J Oral Sci 2003;111(2):149-54. doi: 10.1034/j.1600-0722.2003.00018.x

8. Baratieri LN, Monteiro Junior S, Andrada MAC, Vieira LCC, Ritter AV, Cardoso AC. Odontologia restauradora: fundamentos e possibilidades. São Paulo: Santos; 2001.

9. Blunck U. Improving cervical restorations: a review of materials and techniques. J Adhes Dent 2001;3(1):33-44.

10. Grippo JO. Noncarious cervical lesions: the decision to ignore or restore. J Esthet Dent 1992;4 Suppl:55-64.

11. $\mathrm{Li} \mathrm{H}, \quad$ Burrow MF, Tyas MJ. Nanoleakage of cervical restorations of four dentin bonding systems. J Adhes Dent 2000;2(1):57-65.

12. Carlo B, Barabanti N, Piccinelli G, Faus-Matoses V, Cerutti A. Microbiological characterization and effect of resin composites in cervical lesions. J Clin Exp Dent 20171;9(1):e40-e45. doi: 10.4317/jced.52978.

13. Soares PV, Spini PH, Carvalho VF, Souza PG, Gonzaga RC, Tolentino $\mathrm{AB}$, et al. Esthetic rehabilitation with laminated ceramic venners reinforced by lithium disilicate. Quintessence Int 2014;45(2):129-33. doi: 10.3290/j.qi.a31009.

14. Oz FD, Ergin E, Canatan S. Twenty-four-month clinical performance of different universal adhesives in etch-andrinse, selective etching and self-etch application modes in NCCL - a randomized controlled clinical trial. J Appl Oral Sci 2019;27:e20180358. doi: 10.1590/1678-7757-2018-0358.

15. Correia A, Jurema A, Andrade MR, Borges A, Bresciani E, Caneppele T. clinical evaluation of noncarious cervical lesions of different extensions restored with bulk-fill or conventional resin composite: preliminary results of a randomized clinical trial. Oper Dent 2020;45(1):e11-e20. doi: 10.2341/18-256-C.

16. Loguercio AD, Luque-Martinez IV, Fuentes S, Reis A, Muñoz MA. Effect of dentin roughness on the adhesive performance in non-cariouscervical lesions: a double- 
blind randomized clinical trial. J Dent 2018;69:60-9. doi: 10.1016/j.jdent.2017.09.011.

17. Souza AC, Xavier TA, Platt JA, Borges AL. Effect of base and inlay restorative material on the stress distribution and fracture resustance of weakene premolars. Oper Dent 2015;40(4):e158-66. doi: 10.2341/14-229-L

18. Roscoe MG, Noritomi PY, Novais VER, Soares CJ. Influence of alveolar bone loss, post type, and ferrule presence on the biomechanical behavior of endodontically treated maxillary canines: strain measurement and stress distribution. J Prosthet Dent 2013;110(2):116-26. doi: 10.1016/S00223913(13)60350-9.

19. Soares CJ, Raposo LH, Soares PV, Santos Filho PC, Menezes MS, Soares PB, et al. Effect of different cements on the biomechanical behavior of teeth restored with cast dowel-andcores in vitro and FEA analysis. J Prosthodont 2010;19(2):1307. doi: 10.1111/j.1532-849X.2009.00527.x

20. Farah JW, Craig RG. Finite element stress analysis of a restored axisymmetric first molar. J Dent Res 1974;53(4):85966. doi: 10.1177/00220345740530041701.

21. Joshi S, Mukherjee A, Kheur M, Mehta A. Mechanical performance of endodontically treated teeth. Finite Elem Anal Des 2001;37(8):587-601. doi: 10.1016/S0168874X(00)00059-7.

22. Singh SV, Bhat M, Gupta S, Sharma D, Satija H, Sharma S. Stress distribution of endodontically treated teeth with titanium alloy post and carbon fiber post with different alveolar bone height: a three-dimensional finite element analysis. Eur J Dent 2015;9(3):428-32. doi: 10.4103/13057456.163228.

23. Trindade FZ, Valandro LF, Jager N, Bottino MA, Kleverlaan CJ. Elastic properties of lithium disilicate versus feldspathic inlays: effect on the bonding by $3 \mathrm{~d}$ finite element analysis. J Prosthodont 2018;27(8):741-747. doi: 10.1111/jopr.12550.

24. Kok P, Jager N, Veerman IA, Hafeez N, Kleverlaan CJ, Roeters JF. Effect of a retention groove on the shear bond strength of dentin-bonded restorations. J Prosthet Dent 2016;116(3):382-8 . doi: 10.1016/j. prosdent.2016.01.032.

25. Magni E, Ferrari M, Hickel R, Ilie N. Evaluation of the mechanical properties of dental adhesives and glassionomer cements. Clin Oral Investig 2010;14(1):79-87. doi: 10.1007/s00784-009-0259-3.

26. Archangelo CM, Rocha EP, Anchieta RB, Martin $\mathrm{M} \mathrm{Jr}$, Freitas AC Jr, Ko CC, Cattaneo PM. Influence of buccal cusp reduction when using porcelain laminate veneers in premolars. A comparative study using 3-D finite element analysis. J Prosthodont Res 2011;55(4):221-7. doi: 10.1016/j.jpor.2011.02.005.

27. Machado AC, Soares CJ, Bicalho AA, Raposo L, Soares PV. Stress-strain analysis of premolars with no-carious cervical lesion: influence of restorative material, loaging direction and mechanical fatigue. Oper Dent 2017:42(3):253-65. doi: 10.2341/14-195-L

28. Rees JS. The effect of variation in occlusal loading on the development of abfraction lesions: a finite element study. J Oral Rehabil 2002;29(2):188-93. doi: 10.1046/j.13652842.2002.00836.x

29. Reyes E, Hildebolt C, Langenwalter E, Miley D. Abfractions and attachment loss in teeth with premature contacts in centric relation: clinical observations. J Periodontol 2009;80(12):1955-62. doi: 10.1902/jop.2009.090149.

30. Soares PV, Santos-Filho PC, Gomide JÁ, Araujo CA, Martins LR, Soares CJ. Influence of restorative technique on the biomechanical behavior of endodontically treated maxillary premolars. Part II: strain measurement and stress distribution. J Prosthet Dent 2008;99(2):114-22. doi: 10.1016/S0022-3913(08)60027-X.

31. Soares PV, Santos Filho PC, Soares CJ, Faria VL, Naves MF, Michaejá JA, et al. Non-carious cervical lesions: influence of morphology and load type on biomechanical behavior of maxillary incisors. Aust Dent J 2013; 58(3):306-14. doi: 10.1111/adj.12084.

32. Igarashi Y, Yoshida S, Kanazawa E. The prevalence and morphological types of non-carious cervical lesions (NCCL) in a contemporary sample of people. Odontology 2017;105(4):443-52. doi: 10.1007/s10266-017-0300-y.

33. Aw TC, Lepe X, Johnson GH, Mancl L. Characteristics of noncarious cervical lesion: a clinical investigation. J Am Dent Assoc 2002;133:725-3.

34. Jakupović S, Vuković A, Korać S, Tahmiščija I, Ba- jsman A. The prevalence, distribution and expression of non carious cervical lesions (NCCL) in permanent dentition. Mat Soc Med 2010;22(4):200- 4.

35. Borcic J, Anic I, Urek MM, Ferreri S. The prevalence of noncarious cervical lesions in permanent dentition. J Oral Rehabil 2004;31(2):117-23. doi: 10.1046/j.0305-182x.2003.01223.x.

36. Koidou VP, Chatzopoulos GS, Rosenstiel SF. Quantification of facial and smile esthetics. J Prosthet Dent 2018;119(2):2707. doi: 10.1016/j.prosdent.2017.04.002.

37. Hasija M, Wadhwa D, Miglani S, Meena B, Ansari I, Kohli $\mathrm{S}$. Analysis and comparison of stress distribution in class $\mathrm{V}$ restoration with different restorative materials using finite element analysis. Endodontol 2014;26(2):301-4.

38. Srirekha A, Bashetty K. A comparative analysis of restorative materials used in abfraction lesions in tooth with and without occlusal restoration: three-dimensional finite element analysis. J Conserv Dent 2013;16(2):157-61. doi: 10.4103/0972-0707.108200.

39. Bicalho AA, Pereira RD, Zanatta RF, Franco SD, Tantbirojn $\mathrm{D}$, Versluis $\mathrm{A}$, et al. Incremental filling technique and composite mate-al-part I: cuspal deformation, bond strength, and physical properties. Oper Dent 2014;39(2):71-82. doi: 10.2341/12-441-L.

40. Correia AMO, Tribst JPM, Matos FS, Plját JA, Caneppele TMF, Borges ALS. Polymerization shrinkage stresses in different restorative techniques for non-carious cervical lesions. J Dent 2018;76:68-74. doi: 10.1016/j. jdent.2018.06.010.

41. Barata JS, Casagrande L, Pitoni CM, De Araujo FB, GarciaGodoy F, Groismann S. Influence of gaps in adhesive restorations in the development of secondary caries lesions: an in situ evaluation. Am J Dent 2012;25(4):244-8.

42. Krämer N, Schmidt M, Lücker S, Domann E, Frankenberger R. Glass ionomer cement inhibits secondary caries in an in vitro biofilm model. Clin Oral Investig 2018;22(2):101931. doi: 10.1007/s00784-017-2184-1.

43. Shibata S, Taguchi C, Gondo R, Stolf SC, Baratieri LN. Ceramic veneers and direct-composite cases of amelogenesis imperfecta rehabilitation. Oper Dent 2016;41(3):233-42. doi: 10.2341/15-079-T. 
44. Farias-Neto A, Medeiros FCD, Vilanova L, Simonetti Chaves M, Freire Batista de Araújo JJ. Tooth preparation for ceramic veneers: when less is more. Int J Esthet Dent 2019;14(2):15664.

45. Dejak B, Mlotkowski

A.

Threedimensional finite element analysis of strength and adhesion of composite resin versus ceramic inlays in molars. J Prosthet Dent 2008;99(2):131-40. doi: 10.1016/S00223913(08)60029-3.

46. Magne P, Belser UC. Porcelain versus composite inlays/ onlays: Effects of mechanical loads on stress distribution, adhesion, and crown flexure. Int J Periodontics Restorative Dent 2003;23(6):543-55.

47. Choi JE, Waddell JN, Torr B, Swa MV. Pressed cerircôniato zirconia, part 1:comparison of crystalline phases present, adhesion to a zirconia system and flexural strength. Dent Mater 2011;27(12):1204-12. doi: 10.1016/j.dental.2011.08.006.

48. Lee HE, Lin CL, Wang CH, Cheng CH, Chang CH. Stresses at the cervical lesion of maxillary premolar-a finite element investigation. J Dent 2002;30:283-90.

49. Lee WC, Eakle WS. Stress-induced cervical lesions: review of advances in the past 10 years. J Prosthet Dent 1996;75(5):487-94.

50. Rees JS, Jagger DC. Abfraction lesions: myth or reality? J Esthet Restor Dent 2003;15(5):263-71. doi: 10.1111/j.17088240.2003.tb00297.x.

51. Brandini DA, Trevisan CL, Panzarini SR, Pedrini D. Clinical evaluation of the association between noncarious cervical lesionsand occlusal forces. J Prosthet Dent 2012;108(5):298303. doi: 10.1016/S0022-3913(12)60180-2. 